\title{
Towards a theatre of the tragic: a new critical trajectory for Gao Xingjian's (post-exile) dramaturgy of the riven self
}

\author{
Letizia Fusini ${ }^{1}$ (D)
}

Published online: 7 November 2017

(C) The Author(s) 2018. This article is an open access publication

\begin{abstract}
Although the theatre of Gao Xingjian has been widely researched, the tragic potential of his dramaturgy has hitherto received little attention. Scholars have hinted at the possibility of interpreting certain plays by Gao from the perspective of tragedy; however, this suggestion was never developed into a fullfledged theory. Both his pre and post-exile work has been variously categorized as experimentalist, absurdist, grotesque, and Zen, but never as tragic. Existing scholarship focuses mainly on issues of transnationalism and transculturation with regard to dramatic aesthetics and dramatic technique, whereas Gao's intentional engagement with tragedy as both an art form and a philosophical outlook-which can be traced back to Escape (Taowang 1995), inspired by the Tiananmen Square events of 1989- has generally been overlooked. This paper aims to present a new and fresh critical perspective on Gao Xingjian's (mainly post-exile) dramaturgy of the predicament of modern man through a reexamination of two of its most salient elements: the dramatic technique of shifting pronouns and the performative concept of the "other shore". By elaborating on Gao's transhistorical definition of tragedy as the eternal confrontation between the individual and his own Self ("About Escape" 1990), and drawing on selected scholarship on tragedy and the tragic, this paper ultimately characterizes Gao's plays as "thirdspace tragedies", owing to the presence - at a subtextual level—of an interstitial psychological field dominated by multiple tensions, lacerations, subjugations and divisions which affect the characters and their relationship to external reality and/or the realm of imagination.
\end{abstract}

Keywords Gao Xingjian · Tragedy · Sparagmos · Comparative literature · Thirdspace $\cdot$ Self

Letizia Fusini

L.Fusini@gold.ac.uk

1 Goldsmiths, University of London, 8 Lewisham Way, New Cross, London SE14 6NW, UK 


\section{Introduction}

Gao Xingjian (b. 1940) is an eclectic author, whose artistic pursuit touches upon a number of fields from fiction and poetry to theatre, and from the visual arts to film. Furthermore, the Nobel Prize for Literature, which he received in 2000-13 years after his exile to France-played a crucial role towards his consecration as a leading figure in world literature and also contributed to attracting increasing attention to his works from widening circles of academics and students worldwide. Therefore, a conspicuous body of scholarly publications examining numerous aspects of Gao's œuvre is currently available, most of which focuses specifically on his achievements as a playwright (Zhao 2000; Quah 2004; Łabędzka 2008; Coulter 2014; Mazzilli 2015). ${ }^{1}$ Historically, topics of previous discussions can be subsumed under the following macro-areas of study: the influence of twentieth-century Western avantgarde dramaturgies on Gao's early interest in fulfilling his theatrical ideal of a "modern Eastern drama" (xiandai dongfang de xiju) and how this project also entailed a productive rediscovery of the theatrical traditions of China; the usage of shifting personal pronouns as a writing technique aimed at conveying the complex realities of the human Self as well as to ensuring the anti-illusionistic quality of the performance; the late assimilation of Zen Buddhism into his theatre aesthetics. More recently, a major shift in scholarship has occurred, whereby researchers have turned their attention almost exclusively to consider Gao's post-exile theatrical aesthetics of the so-called "French Plays", 2 which has been reappraised through the lens of transnationalism (Coulter 2014) and postdramatic theory (Mazzilli 2015), thereby contributing to further disengage Gao's later work from the (questionable) categorization of Absurdist theatre.

Nonetheless, a substantial gap still persists in Gao Xingjian scholarship; this concerns the playwright's engagement with tragedy both as a form of drama and a Weltanschauung. Although Gao has never overtly qualified himself as a writer of tragedies, "the tragedy of modern man" (xiandai ren de beiju), as he puts it, seems to be a fundamental concern of most of his post-exile works, particularly of Escape (1990), a play which was written in the aftermath of the 1989 Tiananmen incident, and which bears the subtitle of "a modern tragedy". In a speech delivered at the Royal Dramatic Theatre of Sweden (1991), Gao defined the tragedy of modern man as the impossibility to completely detach oneself from the burden of one's own subjectivity, which he describes as an ambivalent entity: both a vital source of inspiration for the artist and a bosom enemy, it has to be kept at a critical distance in order to prevent it from growing into a tyrannical presence. For Gao, the Self is not a monolithic essence but a multi-layered reality that also involves otherness. Modern man, he maintains, is prey to a sort of internal "other", something that, metaphorically speaking, works like a Trojan horse always ready to break out and strangle the individual to death. It is this constant spiritual tension, Gao observes,

\footnotetext{
${ }^{1}$ These are the main book-length studies discussing Gao's pre- and post-exile dramaturgy. Additionally, Gao's theatre has been examined in a number of articles and edited collections/volumes. See, particularly, Tam (2001), Veg (2010) and Dutrait (1996).

${ }^{2}$ These are a series of bilingual works (French and Chinese) that Gao composed from 1987 onwards, after relocating to Paris where he currently resides.
} 
that constitutes the tragedy of modern man and which he recognizes as a distinguishing feature and trait d'union of Greek, Shakespearean and Modern tragedy alike (2007a, b, p. 70).

Somehow reminiscent of the pessimism expressed by twentieth-century existentialist philosophies, in Gao's dramaturgy this rather gloomy Weltanschauung translates into a persistent tendency to portray characters 'in situation', that is, in agonizing circumstances, which generally revolve around a deep identity crisis. Some characters are lonely and fall easily preys to their psychotic visions, which engulf them consuming their freedom and identity. Others, instead, are entangled in difficult love-hate relationships with the opposite sex. There, the encounter with the other, far from being a pleasant and enriching experience, resembles a fight for survival, a death dance, leading to mutual self-annihilation. These plays, which distinguish themselves for their neutral ambience, universalist character and almost no or little reference to China and Chinese culture, represent a self-standing block of Gao's dramatic repertoire in that they dramatize several types of kunjing, limitsituations in which the individual(s), literally confined within the claustrophobic prison-cell of his/her own individuality, swings between the opposite poles of selfassertion and self-destruction, thus revealing a concrete psychological predicament based on split personality. The usage of limit-situations (kunjing) is itself a manifestation of the tragic, for, according to William Storm, "the tragic may be finally understood as a 'situation', and one that is both stringent and provocative: a set of enforced conditions that, because of their nature and impact, suggest both a participation and a response." (pp.90-91) Furthermore, the notion of kunjing ties in with J. P. Sartre's theory of a dramaturgy of situations, which, as Victor Brombert has noted, was greatly inspired by (Greek) tragedy (p. 158).

The theme of the identity crisis is conveyed through the typically Gaoian device of tripartite acting (biaoyan de sanzhongxing), a dramatic technique consisting in approaching the role from an estranged, neutral perspective, involving the shifting usage of third- and second-person pronouns, and which has been generally described as a method of self-introspection and quiet observation that the actorcharacter deploys in order to balance his/her personal, dramatic and theatrical identities. However, rather than conveying a Zen-like attitude to the observe the mind, or a Brecht-like detached and scientifically-driven outlook towards the staged events, below I argue that such a technique tangibly encapsulates the abovementioned dilemma of the Self, its intrinsic fractures and ambivalence, and, what is more, not disregarding the portrayal of negative emotions, primitive passions and repressed instincts.

While Henry Zhao has only succinctly noted that “all of Gao's Zen [post-exile] plays are tragedies" (p. 33), and Izabella Łabędzka has alluded to a possible redefinition of all his dramatic auvre as "infra-tragedy"3 (p. 174), hitherto these rather embryonic ideas were never developed into a full-fledged theory or critical proposition. This study aims therefore to initiate a reassessment of Gao Xingjian's

\footnotetext{
3 Coined by Jean-Marie Domenach in his 1967 essay Le Retour du Tragique (The Return of the Tragic), "infra-tragedy" is a neologism which designates the tragedy of the common man and of everyday life through the collapse of a once glorious dramatic genre into the "lower" realm of comedy, as suggested by the Latin prefix infra which means "beneath, below".
} 
(mainly post-exile) dramaturgy of tensions, lacerations, subjugations and divisions, by re-examining two key Gaoian tropes such as the dramatic technique of shifting pronouns (rencheng de zhuanhuan) and the motif of the "other shore" (bi'an). The ultimate goal is to try and extrapolate the tragic potential of Gao's dramaturgy through a fresh methodological framework based on a combination of critical approaches within the purview of contemporary tragic theory (Storm, Cowan). In particular, my analysis, which will be exclusively text-based, will be guided by William Storm's theory of the tragic as a Dionysian mechanism (1998) and the related concept of "tragic latency" (p. 81), whereby Gao's "plays of the riven Self" - as I define them to distinguish them from the rest of his repertoire-would derive their tragic essence not from "a stock of variable and amendable plots and fabulae" (Sacco 2013, p. 184) retrieved from a universally-accepted tragic canon and rewritten by the author, but from a less visible third space, a dynamic realm of potentialities that can be fully activated only through an ad hoc methodological exploration. As will be shown below, the tragic latency of Gao's dramaturgy coincides with what René Habachi has termed "the intuition of something riven" (1985, p. 9), an ancestral wound that never heals, precipitating each individual into a bottomless abyss, where darkness can suddenly turn into a light that channels a profound truth about the human being.

Overall, this paper will first explore and elaborate on Gao Xingjian's philosophical idea of the tragic Self by placing it in the wider context of likeminded critics and scholars. Next, I will reconfigure Gao's tripartite acting as a form of sparagmos, based on Storm's Dionysian-based reconceptualization of tragedy. Third, the concept of "other shore" will be scrutinized and reinterpreted through a dedicated analysis of Gao's eponymous 1986 play and through Storm's theory of the tragic field. Occasional references to other plays by Gao will be made, when appropriate. Ultimately, I will conclude by explaining my proposal to re-define Gao's plays of the riven Self as "thirdspace tragedies", and will suggest a possible way of extending this research towards new critical trajectories.

\section{The Daimon within: Gao's idea of the tragic self}

As laconic as it may appear, Gao's personal equation of tragedy with the misfortune coming "not only from [...] the will of others" but also "from the Self," (2007a, b, p. 70), resonates with the idea-upheld by many ${ }^{4}$ - that the common denominator of tragedies from the Greeks to the present day be "a transcendent inquiry into the nature and limitations of the Self” (Storm 1998, p. 51). The uncanny encounter between the individual and his own Self disguised as an Other is regulated by a mechanism which, according to William Storm, affects the relationship between "character and theatrical cosmos" (Ibid., p. 85) and engenders a dynamics of cohesion and division with respect to this other-within-the-Self that is a major

\footnotetext{
${ }^{4}$ Most notably Steiner (1961), Paul Ricœur (1992), Richmond Hathorn (1962) and Lukács (1981), among others, have highlighted the importance of these dynamics towards the formation of tragedy and its dramatic structures.
} 
presence in Gao's plays. The archetype of the devastating Other "outside and within man", which "waits for us in ambush at the crossroads", that "mocks us and destroys us" "lead[ing] us after destruction to some incomprehensible repose" (1961, pp. 8-9), to say it with George Steiner, and that represents "a fixed opposition within the constitution of selfhood," (2008, p. 176) as Paul Ricœur contends, is interestingly defined by György Lukács as an "experiential mode", a subjective response to what he calls "the experiencing of the frontier between life and death," (1981, p. 82) an aspect which Gao has explored in his eponymous postexile piece Between Life and Death ${ }^{5}$ (1991) but that variously permeates all his post-exile plays of Self.

In an interview with Noël Dutrait, Gao depicts the Self as the equivalent of "a black hole, capable of sucking everything in" and defines it as simply "terrifying" (Lee and Dutrait, 2001, p. 743). This gloomy metaphor can be decoded through Louise Cowan's definition of the tragic as "the experience of the abyss, as if one had fallen into a black hole in inner or outer space" (2003, p. 9). Furthermore, Cowan's conception of the tragic as a metaphysical reality which pre-exists dramatic tragedy seems to accommodate Gao's tendency to envision tragedy primarily as a structure of existence, an inescapable destiny that inheres within our human genes; not a man-made way of interpreting reality, but a reality itself "to which art responds" as William Storm too contends (p. 71). Under this light, Gao's association of tragedy with the disruptive mechanisms of the psyche-which I here intend in the classical sense of "soul/mind" — not only proves unaffected by a certain contemporary popular stereotype, whereby tragic be synonymous with "very sad", but would also confirm Cowan's assumption that "tragedy [...] is primarily concerned not so much with examining philosophical ideas or ethical standards as with discerning the tension at the heart of being, to which mortals resonate in their depths." (p. 7, emphasis added) Gao's observation that "theatre should deal with life rather than philosophy" (Gao and Fang 2010, p. 117) is a further evidence of his view of tragedy as rooted in the factuality of dayliness.

But what is the mechanism leading to the degeneration of the Self into a tyrannical Ego and an infernal Other? Arguably, this is linked to way in which Gao envisions the relationship between Self and Other. As Gilbert Fong observes, for Gao "the relationship between the first-person self and his 'other' hands in a delicate balance, covering the whole spectrum of subjectivity and objectivity" (1999, p. XXIV). Conversely, it is when the process of self-transcendence, leading to the formation of what Gao calls "a thread of consciousness" (2000) comes to an end, that the internal "otherness" prevails thereby transforming itself into the source of the individual's predicament: a second and obscure Self. According to Fong, Gao's perception of the Other-within-the-Self can be conceptualized in Lacanian terms whereby “' 'otherness' can never be firmly grasped. The other is basically a locus of the subject's fears and dears; they do not belong to an external category, but are internal and unchangeable conditions of man's existence." (1999, p. XXIII).

I would argue that Gao's idea of the tragic Self can be more correctly understood in conjunction with Jean-Paul Sartre's theory of being and nothingness with respect

\footnotetext{
5 BLD hereafter.
} 
to the human Self. In short, Sartre argues that the being of man, which he calls the "in-itself" (être-en-soi), and which forms part of the individual's identity, is not a preordained entity but equals the sums of the individual's personal choices and the related acts. Man is constantly obliged to make choices thereby "choosing" his own nature or identity. The act of choosing can only be accomplished by the consciousness, termed the "for-itself" (être-pour-soi). Consciousness can soar up above the "in-itself" and guide it and dominate it by redefining it constantly. In other words, for Sartre, each individual is whom his/her consciousness decides to become. Failure to choose equals the refusal to redefine one's individuality and inevitably leads to a kind of spiritual death. The "in-itself", in fact, represents a potential enemy for the individual's personality due to its tendency to become redundant and superfluous once the individual refrains from the moral obligation to choose. Sartre characterizes the "in-itself" as potentially "viscous", namely sticky and slimy and with a tendency "to engulf us like a leech in its softness" (Lavine 1984, p. 402). Moreover, similarly to Gao's notion of the Self as an antagonistic presence, Sartre envisions the relationship between the "in-itself" and the "foritself" as an unremitting struggle for either's predominance. Sartre's description of such an internal fight closely resembles Gao's description of the tragic Self discussed above. For Sartre, "The viscous is docile. Only at the very moment when I believe that I possess it, behold, by a curious reversal it possesses me ... I want to get rid of the viscous and it sticks to me, it draws me, it sucks at me ... Here we can see the symbol which abruptly discloses itself: there exists a poisonous possession; there is the possibility that the In-itself might absorb the For-itself." (1992, p. 776). Moreover, for Sartre, what is equally "viscous" is the look of the others. This can act like Medusa's gaze which would turn onlookers into stone. The other's look is for Sartre as infernal and tyrannical as the-Other-within-the-Self is for Gao, because it is capable of unmasking the individual's bad faith thereby ratifying the in-itself's dominant power over the Self of the objectified individual.

Finally, another trait d'union between Gao's and Sartre's respective ideas on the predicament of the modern man lies in the final discovery that the Self of the individual is actually grounded in nothingness. ${ }^{6}$ This means that even when the individual is able to enter the realm of self-consciousness, thereby viewing his own self from a distance, he experiences the disillusionment of not being able to control it. It does not let the individual get hold of it, simply because, although it is, it is not there. Therefore, and similarly to Sartre, for Gao the Self is an all-absorbing entity, whereas the fundamental project of consciousness (the for-itself, for Sartre), that is the desire to overcome its nothingness and become one with the Self (for Sartre, this equals becoming like God), is bound to fail. Consciousness cannot fully control or grasp the Self, because whereas the self is "viscous" and can be defined as "presence", consciousness is volatile and can be defined as "lack".

However, Gao's notion of the Self as the source of the tragic, somehow differs from the Sartrian view in that for Gao, the tragic seems to emerge from the idea that

\footnotetext{
6 The connection between Gao and Sartre on the element of nothingness, with some references to Daoism and Zhuangzi's thought, has also been succinctly touched upon by Sy Ren Quah in Gao Xingjian and Transcultural Chinese Theatre, 2004.
} 
subjectivity be a fundamentally un-safe haven, a space that the individual clings to as a precious sanctuary, in which he thinks he can find freedom, knowledge and selffulfilment but that eventually turns out to be the opposite. For Gao's post-exile characters, to enter the realm of the Self means ultimately to end up being locked inside a trap-like antechamber, and fall prey to forces, which are born from the deepest crevices of the individual's subjectivity but, which, nevertheless, paddle against him like maelstroms in a whirlpool. Each of Gao's post-exile plays of Self features a similar manifestation of the tragic as a reversal-mechanism, which bears a striking connection to what Aristotle termed as peripeteia: a sudden reversal of circumstances. In $B L D$, for example, a woman delves into her past memories as a way of comprehending her own Self; in other words, she seeks refuge in her own subjectivity. However, her self-immersion into the retreat of the ego, far from offering her the solace and enlightenment she pursues, turns into a regular descent into hell, which not only intensifies her initial anguish and sense of disorientation, but also further deprives her of her identity. Further examples can be found in Nocturnal Wanderer $(1994)^{7}$ and The Death Collector $(2002) .{ }^{8}$ In the first case, a traveller seeks shelter in a dream, which expresses the fantasies of omnipotence being nurtured by its subconscious. Transformed into a completely free individual by a mysterious Voice, which I interpret as his "other-within-the-Self", he becomes gradually prey of his own most evil impulses, ending up committing various homicides and ultimately being killed by a Masked Man, who represents the personification of his inner ego. In the second case, an old man seeks temporary shelter in a physical place-a museum-which eventually turns into his grave. I argue that the museum, where he remains inexplicably locked inside, and from which he initially attempts to escape, functions as an allegory of his difficulty accepting mortality and finitude as engrained in human nature. As he voices a number of contradictory thoughts and statements, counterbalanced by those of a mysterious alter-ego, he reaches the height of his madness by committing suicide.

What these examples show, with regard to the tragic nature of the Gaoian Self, is that Gao subjectivity is absolutely not a continuum. On a macro-level, the characters' consciousness is always split into a series of alter-egos, which can either appear as independent characters or as shadowy figures. For example, in Escape, the three protagonists are all physical individuals who act as reciprocal torturers, whereas in the three plays mentioned above, the lonely protagonist is crushed by his/her own personal ghosts/phantasms. Given its tendency to fall apart and due to its always being in a state of flux "encompassing past and present, good and evil, long-lasting guilt and brief happiness, and life and death" (Fong 1999, p. XXIII), the Gaoian Self is tragic because it consists of many fragments, torn between selfconsciousness and the consciousness of the Other living inside the Self, in a neverending inner conflict. From a strictly literary viewpoint, Gao expresses the tensions generated by the split in the subject's mind through the shifting usage of personal pronouns as his favourite narrative and dramatic technique. To him, in each character three psychological dimensions coexist. The Self can simultaneously be

\footnotetext{
${ }^{7} \mathrm{NW}$ hereafter.

${ }^{8} T D C$ hereafter.
} 
an "I", a "You" or a "He" or "She". These pronouns represent the individual's possible ways to address his own Self, not only in order to observe it from an external perspective but also to control it. However, while in Gao's novels this technique enables the character to achieve a serene and deeper understanding of his own Self, in a dramatic context this mechanism leads the character to experience the loss of control on the Self and to perceive the latter as an overwhelming presence.

To summarize, Gao's concept of the tragic Self can be described as both a quiescent and obscure force residing in the innermost depths of an individual's soul, and a terrifying presence that once activated or "awakened" turns itself into an overwhelming creature, inexorably haunting and possessing the individual's psyche, thereby revealing dark areas of personality that were previously unknown. Therefore, the Gaoian tragic Self appears to fit within the ancient Greek concept of the daimon, exemplified by several canonical tragedies from Oedipus to Macbeth, and from Phèdre to Caligula, which decree the terrible truth that (tragic) destiny and the Self virtually coincide. In Gao's case, an example thereof is manifest in the words of the character of That Man in TDC who forcefully proclaims: "There is no need for such ranting. It's all in your destiny. [...] You can't escape even if you want to." (2007a, b, p. 87) And later, again: "What's absolutely certain is that you'll have to die sooner or later. Death is waiting for you, whatever you do or don't do. There is no escape from this ending." (Ibid., p. 88).

Next, I will investigate how Gao's philosophical idea of the Other-within-theSelf materializes in a dramatic context, thereby complying with Peter Szondi's observation that any theory of tragedy cannot be based solely on philosophical reflections but on the analysis of a set of "concrete elements" (2002, p. 56) that form its nucleus. Consequently, the analysis below will show that Gao's dramaturgical implementation of the tragic in his post-exile plays sits quite at a distance from what is known as das Tragische in German Romanticism, the latter being configured as an abstract, intellectual category, while the former presents itself as the dramatization of a constitutive element of human nature and psychology.

\section{Performing (in) the tragic mode: tripartite acting as a form of Sparagmos}

While much has been said about Gao Xingjian's dramatic technique of shifting pronouns (Lee 2001; Quah 2004; Veg 2010, among others), ${ }^{9}$ the rather contradictory relationship between its theoretical formulation in Gao's writings and its concrete use in the plays has received less critical attention. Constructed around the two poles of Self (wo) and Self-consciousness (ziwo), and revealing a complex psychological stratification (xinli cengci) within the actor-character's body-mind, tripartite performance consists in a combination of participated actions performed in the first person and alienated, often emotionally loaded storytelling performed using the third or the second person. A personalized revisitation of the Brechtian V-effect,

\footnotetext{
9 Variously translated as tripartition or triplication.
} 
whereby actors avoid direct impersonation of and emotional identification with the role, Gao's tripartite performance presupposes that the actor reaches a condition of complete neutrality in order to lend his own body to serve as a tabula rasa for depicting the character's own psychology. The neutral attitude (zhongxing de yanyuan de taidu), intrinsically mimetic and extrinsically anti-naturalistic, would be in keeping with traditional Chinese theatre performance techniques, which are based on a sound balance of dramaticality and theatricality. Furthermore, according to Gao, neutrality consists in developing "a third eye" (1996, p. 257) which helps control and harmonize the performance, boosting the actors' ability to observe themselves, the audience and the role, balancing pure acting with reflection and character-analysis. In other words,-Gao maintains - the actor steps in and out of the role with the aim of channelling the character's potential influence on his personality.

Nevertheless, it seems to me that rather than exerting an authoritative power over the character's Self, the actor embraces the latter's emotional predicament to the point of generating a situation of split personality. In Gao's post-exile plays, this typically culminates in the loss of any cognition about who the actor-character actually is, thereby leading him to ask whether there is, after all, an entity called "Self". By opening up the recesses of the Self, those "intervals and dualities between the performed self and the performing self", (von Held 2011, p. 260) Gao seems to compel the performer to go through what looks like a rending mechanism, resulting from an internal fight that affects actor and character alike, thereby nurturing the perception of the individual as a bunch of fragments. This becomes the dramatic translation of Gao's philosophical idea of modern man's predicament, the leading theme of the post-exile plays and the main source of tragic tension, as show below.

As I propose, such a rending mechanism can be reinterpreted as a form of sparagmos, originally a ritual performed (or undergone) by the god Dionysus, which involved the physical dismemberment of a sacrificial animal (typically a goat). William Storm, in After Dionysus, constructed a theory of the tragic in light of the Dionysian element and mostly with regard to the figure of Dionysus, the Greek god of intoxication but also of split personality and theatre, as he appears in Euripides' The Bacchae, the only extant tragedy featuring the god as an active character within the drama. Storm's understanding of the tragic as an unmendable conflict, a divisive mechanism and a dramatic mode based on psychical disintegration, and of tragedy as the site in which this tragic process occurs, thereby leaving aside sterile structural categorizations, provides a fitting framework for rethinking the dynamics and intrinsic meaning of Gao's tripartite performance.

In Gao's dramaturgy of shifting pronouns, the actor-character's Self is presented as a disaggregated unit which epitomizes the internal feeling of laceration experienced by the dramatis persona and narrated/performed by the actor. Specifically, the "you" form and the "(s)he" form function both as modes of estrangement (juli fa) for better highlighting the character's psychological conflict and as mirrored-images of the character's actual feeling of estrangement to his own self (juli gan). In this way, the Self is objectified, dissected but never recomposed, because the metaphorical process of dismemberment is not reversible. This proves 
Gao's absolute distance from the Nietzschean notion of the Dionysiac-tragic, since, for Nietzsche, the Dionysian sparagmos is always followed by the resurrection of the individual, not as such but as part of the universal Whole.

The process of transference of the sparagmos mechanism from the character to the neutral actor resembles what happens between Dionysus and his cousin Pentheus in Euripides' tragedy. Dionysus - an allegory of the character, disguises Pentheusan allegory of the actor-as an-other Self, thereby making the latter as an alter-ego of himself. During his dialogue with his cousin, Dionysus frequently otherizes himself, referring to himself as a "he". Moreover, when recalling the scene in which Pentheus frenziedly attempts to catch the malevolent god, Dionysus talks about assuming a concurrently triple role as himself (invisible to Pentheus), as a sacred bull (an hallucination) and as Dionysus the god. Similarly, when Pentheus goes to see the maenads, he is simultaneously himself (a disguised body) and Dionysus (an invisible spirit who drives him where he wants). Shortly before getting his body physically dismembered by the women, Pentheus starts showing the signs of an interior(ized) sparagmos, thereby confirming the idea that the process of sparagmos should not be necessarily meant as a literal dismemberment or a physical death.

In Gao's post-exile plays, the individual is simultaneously Self and Other, but his individuality is also made of deeply interconnected fragments. Whether it is a body who performs and a voice who narrates (in the third person), or interacts with itself (in the second person), or communicates with a second character (in the first person), there is always an interstitial thirdspace characterized by conflicting energies whose collision generates a multiplicity of rifts and cracks. The individual does not speculate on the tragic, nor does he put forward a tragic vision of his own; rather, he performs in the tragic mode, experiencing and communicating a kind of "morphogenetic fracture [...] a boundless caesura, an immense and unmendable crisis, [...] which cannot be compared to whatsoever other generative force." (Capodivacca 2010, p. 57)

There are various ways in which Gao's triadic dramatis personae undergo the lure of Dionysus, the god of character. Under the influx of a daimonic and invisible "She", the lonely Woman in $B L D$ rapidly turns into a maenad and brutally kills her lover, as if in a dream. Nevertheless, afterwards she finds her own act unconceivable and she feels the need to explore her own Self to understand who she actually is, but to no avail. Her mind and body undergo a lengthy process of serialized dismemberments conveyed through a plethora of psychotic hallucinations evoking images of angst and terror and culminating in her transformation into a mere stage prop-a bunch of abandoned clothes signifying the fragments of herself, her mind emptied of any clear sense of identity. Under the influx of a Dionysian-like voice, the mysterious Traveller in NW (1994) creates a new identity for himself-that of the titular Nocturnal Wanderer-but, due to an unprecedented drive to violence, which turns him into a serial-killer, he ends up not recognizing himself any more as the person he thought he was. This dark side of his Soul is eventually symbolized by the figure of the Masked Man who enters the stage in order to kidnap him. In Dialogue and Rebuttal ${ }^{10}$ (1993), a Man and a Girl, who are presumably occasional

${ }^{10} D \& R$ hereafter. 
lovers, attempt desperately to seize each other's Selves in what looks like a deathdance who they both perform. Nevertheless, they end up confronting the reality of the Self (through the dismemberment of verbal language) as essentially cracked, which leads them to the loss of human identity. Finally, in $T D C$, under the evil influx of That Man, This Man, an old and neurotic individual, hangs himself after realizing that what stands in front of him is a big black hole, an abyss of darkness and oblivion. Overall, these inescapable dynamics of conflicts, intersections, doubling and fragmentation lead to the massacre of the Self through a violent, and repeated Dionysian act of sparagmos. The loss of Self, which is the common denominator of all the above-mentioned plays and the result of an internal possession by the characters' internal Dionysus, may have different articulations: from reification $(B L D, T D C)$ and posthuman metamorphosis $(D \& R)$ to the complete disappearance of the human body $(N W)$.

Hyper-divisiveness being their main mode of existence (and performance), Gao's post-exile characters appear to fulfil Storm's definition of "the reconceived tragic man", as their tragic status, far from being the mere product of a certain tragic Weltanschauung "is defined by the range of potential divisions that such a condition invariably implies." (1999a, b, c, d, p. 90) Therefore, by reconceptualising Gao's performance mode as a manifestation of the tragic that inheres in the universe as an ancestral reality, one can cast a new and refreshed perspective on the rather vague concept of "performance in alienated voices" (Quah 2004, p. 130), initially coined to make sense of this specific dramatic device. As previously shown, Gao's characters are not "alienated" in the sense of being isolated from the outside world, unable to communicate with their fellow human beings and simultaneously estranged from themselves in the often failed attempt to free themselves from their own subjectivities; they are rather variously possessed by their internal daimon. They do not experience an "alienation" of personality but rather an invasion of personality from within as they perform an exploration of their own enigmatic subjectivities. The outcome of such a powerful invasion is not the impossibility to get rid of the Self but the frustration of being left with bits and pieces of it. Following from Richard Hornby's metadramatic theories, Gao's characters can be said to role-play to signify not only their split personality but also their ontological insecurity (1986, p. 81). As with Ibsen's Peer Gynt, who is regarded as a classic prototype of a role-playing figure (Ibid. 80), the tragic potential of Gao's characters resides in the contradiction between having multiple identities and having none. Ibsen uses the gesture performed by Peer of peeling an onion as a metaphor of searching for the core of his Self, which lies under the several layers of his previous identities. Still, he finds out that there is no kernel at all. Similarly, Gao's characters delve deeply into their Self, searching every corner of it, but end up being consumed by it, swallowed up in a tunnel of darkness, possibly with more tragic implications than Peer's. 


\section{Performing the tragic field: "the other shore" from individual play to dramatic trope}

The genesis of what I have re-defined above as the Gaoian "tragic mode" may be traced back to the pre-exile play The Other Shore (1986), which ends with the doubling of the character of Man who eventually leaves the stage in a peaceful state of mind, accompanied by the personification of his own consciousness, ${ }^{11}$ embodied by the new born character of Shadow. Although the first experiments with the device of the neutral performer had previously occurred in Bus Stop (1982), in that case it was introduced rather abruptly as a coup de théâtre and as a means of shocking the audience and stimulating a critical response towards the characters' behaviour on stage. In The Other Shore, ${ }^{12}$ instead, the final sparagmos of the protagonist's identity is presented as the outcome of a lengthy and rocky dramatic process aimed at achieving self-knowledge. Less theatrical than dramatic, this strikingly resonates with both the ancient Greek aphorism of "know thyself" (gnoti seauton) and the tragic slogan of pathei mathos, or learning through suffering, which will be further developed throughout the post-exile repertoire.

Originally conceived as an exercise for actors, TOS not only marks a watershed in Gao's aesthetics-due to its mythical and universalistic content, its abstractness and loose episodic structure-but also inaugurates a new theatrical discourse oriented towards the tragic. In this play, I argue, the tragic trope of the other-withinthe-self is explored through the construction of a (meta-)dramatic space, which is itself imbued with "otherness" and Dionysian traits, and which will resurface prominently in Gao's subsequent post-exile plays of Self as a fully-fledged dramatic trope.

Below, I will first seek to demonstrate that TOS is centred on the construction of a theatrical and psychical field based on conflicting energies and functioning as a dramatic avatar of the most secret and obscure mechanisms of the human psyche. Next, I will document the reappearance of the other shore as a dramatic trope of Gao's post-exile plays of Self through a few specific examples.

TOS features a group of actors led by an instructor who trains them through a series of acting exercises and guides them to reach a hypothetical "other shore", which they have to create by themselves through their imagination. Once "on the other shore", the actors lose their ability to speak and their identities are melt into that of an anonymous and maddening Crowd, a sort of collective actor out of which individual archetypes such as Man, Woman, Mother, Girl etc. later come into being. As a psychical field, I argue that the "other shore" in TOS constitutes the dramatic incarnation of Storm's theory of "the tragic field". Drawing on Katherine Hayles' application of the field concept of quantum physics in the arena of literary studies and on Edmund Burke's "dramatistic model" for character analysis, Storm argues that the tragic condition translates artistically into a field of opposite forces-

\footnotetext{
11 The character in question (Shadow) asserts to be Man's Heart (xin). However, in Chinese there is no ontological difference between the heart and the mind, which are regarded as one and the same. It can therefore be surmised that Shadow embodies Man's consciousness.
}

12 TOS hereafter. 
cohesive and divisive-orchestrated by Dionysus and leading to the spiritual disintegration of the individual's Self (source). This is what happens to the character of Man, who undergoes a process of both mental and physical sparagmos since his "rebirth" on the other shore. However, the sparagmos ultimately results from an intricate system of relations between Man and the other characters, who attempt to impede his search for freedom and self-knowledge.

As I will show below, the Gaoian "other shore" fits Storm's identification of the tragic field with "a kinetic space around the characters" (1998, p. 96), which starts to form at the very beginning of the play. The game of ropes that the actors initially perform under the supervision of their instructor sets the premises for the play's progressive development into a well-defined tragic field of opposite forces. By comparing human society to a "tug-of-war" where "the stronger one pulls and the weaker is being pulled" (1999a, b, c, d, p. 3), the Leading Actor suggests that real human relationships are fundamentally ambivalent, as denoted by the interplay of centripetal and centrifugal forces on which they are grounded. On the other shore, these simultaneously cohesive and divisive relationships give birth to an archetypal universe, a primordial chaos fuelled by the constant movement of a pool of characters acting as energy particles whose mutual interactions create "interstitial spaces" (Storm 1998, p. 113) comparable to energetic passages. The other shore, originally a Buddhist concept which indicates a mental state of absolute freedom from the evils of the secular world, becomes herein a chthonian underworld, an "existential twilight zone" (Schlesier 1993, p. 14) and a Dionysian realm par excellence, where chaos and primordial oneness reign.

Torn between his desire to pursue his own life aspirations-including reclaiming his own Self-and the repeated assaults of a delirious and homogenizing Crowd, who reclaims him as their leader, the character of Man ends up being dismembered into two separate yet interconnected entities: himself and his consciousness who drags him away from the other shore, saving him from mental derailment. Man's final physical-cum-mental sparagmos, which is provoked also by the encounter with several Dionysian figures, such as the cunning Card Player, is the result of a tragic field of attempted cohesion (with himself) and division (from himself).

Defined as "a world of the dead" (1999a, b, c, d, p. 20) by Man, the other shore qualifies as a dimension of indeterminacy and darkness, a world of shadows which are hungry for the Self of others. Moreover, the other shore is also a kind of extended projection of the Self; the Self that creates another world in which he wants to take refuge but that proves a breeding-ground for his own inner ghosts to become alive and grow mad at him. Instead of enlightenment, the other shore provides a dark abyss of spiritual death, which is a recurring feature of the post-exile plays mentioned above. Specifically, in $B L D$ and $N W$, the other shore coincides with the descent into a sort of underworld of the Self incarnated, respectively, by a locked room transfigured by Woman's progressive metadramatic delirium, and by an oneiric nocturnal city transformed into a pan-Dionysian realm by Traveller's egotistic subjectivity. In both cases, the other shore is a construction of the sick imagination of the two protagonists and becomes a tragic field of cohesion and division through the characters' continuous clashes with a plethora of opponents (a male lover plus several mysterious figures in $B L D$ and a group of criminals/ 
outsiders in $N W$ ) symbolizing the Dionysian Other, who turns the Self from an idealized (and idolized) haven into a hell-on-earth and an inescapable trap. In these two plays, the tragic field is, respectively, spatialized and psychologized. In $D \& R$, the other shore corresponds to the realm of gender relationships, a world that appears as a network of cracks, rifts, thresholds and borders, where an archetypal couple employs various types of role-playing as a means of self-protection whilst seeking to subjugate the other. Even after they behead each other, they continue to fuel the tragic field by experiencing and voicing the same predicament of being at one's wits' end. Here, the tragic field eventuates in the sparagmos of verbal language and in the discovery that beyond words is nothing but "a crack line", that is, the essence of the tragic. Finally, in $T D C$ the other shore is a contemporary art museum who progressively turns into a symbol of spiritual degradation and a realm of psychotic visions. The tragic field is activated through the verbal confrontation between the protagonist and his uncanny alter-ego: a relationship of seductions and deceptions that resembles the negotiation between Pentheus and Dionysus and which will push the main character towards a futile and meaningless suicide.

In the post-exile plays of Self, the other shore as tragic field takes on various appearances to express a shared message: the equation of tragedy, theatre and life. This is in line with Gao's definition of existence as an endless tragedy. Simultaneously familiar and disquieting, heimlich and unheimlich, the other shore is compatible with George Bataille's concept of "mother-tragedy" (mère-tragédie), whereby theatre "belongs to the realm of the stomach, to the infernal and maternal world of the deep earth, to the black world of Chthonian divinities" and existence "is linked to the tragic insofar as it does not belie the humid soil that begot it and to which it will return" (Bataille 1970, pp. 493-494). Furthermore, all these plays are pervaded with images of sparagmos, or rending experiences, which tighten up the tragic tension throughout. ${ }^{13}$

To conclude, the other shore or the tragic field as it is constructed and fuelled by the Gaoian characters aptly mirrors Louise Cowan's definition of the tragic protagonist as someone who "has to descend into the deepest crevices of the universe-into Tartarus itself." (2003, p. 13)

\section{Conclusion}

The purpose of this paper has been to present a new and fresh critical perspective on Gao Xingjian's (mainly post-exile) dramaturgy of the predicament of modern man through a re-examination of two of its most salient elements: the dramatic technique of shifting pronouns and the performative concept of the "other shore". Starting from Gao's identification of the problem of the ambivalence of the Self as a typical tragic motif from the ancient to the modern, I have sought to extrapolate the tragic

\footnotetext{
13 While most of these examples can be found in $B L D$, where I identified five types of sparagmos: interpersonal (Woman's schizophrenic and maenad-like behavior towards her lover), intrapersonal (Woman's disintegration of her gendered subjectivity), scenographical (Woman's physical dismemberment), allegorical (Woman being terrified by the sight of a Buddhist nun who cuts her belly extracting her guts) and metaphysical (Woman who sees multiple heads around her).
} 
potential of Gao's dramaturgy of the riven Self by applying concepts and theories of tragedy such as Louise Cowan's theory of the tragic abyss, and William Storm's notion of the tragic field-based on his reconceptualization of tragedy as the artistic re-enactment of the Dionysian ritual of sparagmos. Under this new light, Gao's theory and practice of the tripartite actor has been reconfigured as "performance in the tragic mode". Rather than facilitating an attitude of quiet and distant contemplation of the Self, for the Gaoian characters the Self is torn apart, thereby generating or acknowledging the presence of an Other or multiple Others. Similarly, the "other shore" has been redefined as a network of concurrently cohesive and divisive relations linking its inhabitants to what seems to be a kind of magnetic field of opposite energies that revolves around the individual and his own Self.

Finally, this new critical trajectory challenges Izabella Łabędzka's association of Gao's plays with the concept of infra-tragedy. Gao's tragic dramas do not represent the tragedies of everyday life, nor do they dramatize human wrecks to suggest the absurd core of life. Rather, as previously argued, by exposing us to the abyss of living, they urge us to confront that threshold which marks both the origin and the end of things. Drawing on Louise Cowan's argument about tragedy, this thesis maintains that at the core of Gao's newly-conceptualized tragedies, there is "the experience of the abyss, as if one had fallen into a black hole in inner or outer space" (2003, p. 15). And it is precisely this condition of in-betweenness, this threshold between psychic and real spaces, this emphasis on interstices, cracks and boundaries that urges us to search for an alternative to infra-tragedy. One needs to substitute the inferiority paradigm (infra) with a reference to liminality and depth. Gao's tragic plays could then be renamed as "thirdspace tragedies", a concept that not only draws on Homi Bhabha's and Edward Soja's theories of thirdspace, but also represents a further development of Storm's idea of tragedy as a relational field based on a connective fabric stemming from the characters' mutual relations. Since thirdspace is still an ambiguous and enigmatic concept, it is potentially applicable to a variety of critical contexts and cultural phenomena. Bhabha characterizes it as a "realm of the beyond" (1994, p. 4), thus echoing Jean-Pierre Vernant's idea of tragedy as representing an invisible elsewhere (an other shore, c1986, p. 18). Soja describes it as "a creative recombination and extension" of a Firstspace (i.e. real) and a Secondspace (i.e. imagined) perspective, but, most importantly, as a "secret and conjectured object, filled with illusions and allusions, a space that is common to all of us yet never able to be completely seen and understood, an 'unimaginable universe'." (1996, p. 56).

Combining these observations, one could define the Gaoian thirdspace tragedy as a drama that, by working between opposite polarities - self and other, cohesion and division, reality and imagination, antiquity and modernity-actually occurs within a less visible thirdspace, a dynamic realm of potentialities (and Dionysus $i s$, himself, a potency), that can be fully brought to surface only through an ad hoc methodological exploration. And it is in this precise thirdspace that the Gaoian tragic potential can be revealed and darkness can suddenly turn into a light that channels a profound truth about the human being. 
Open Access This article is distributed under the terms of the Creative Commons Attribution 4.0 International License (http://creativecommons.org/licenses/by/4.0/), which permits unrestricted use, distribution, and reproduction in any medium, provided you give appropriate credit to the original author(s) and the source, provide a link to the Creative Commons license, and indicate if changes were made.

\section{References}

Bataille, G. (1970). Euvres complètes (Complete works). Paris: Gallimard.

Bhabha, H. (1994). The location of culture. London: Routledge.

Brombert, V. (1964). Sartre and the drama of ensnarement. In J. Gassner (Ed.), Ideas in the drama (pp. 155-174). New York: Columbia University Press.

Capodivacca, S. (2010). Sul tragico. Tra Nietzsche e Freud (On the tragic. Between Nietzsche and Freud). PhD Dissertation, University of Padua.

Cools, A. (2008). Selfhood as the locus of the tragic in Paul Ricœur's Soi-même comme autre. In A. Cools (Ed.), The locus of tragedy (pp. 165-180). Leiden: Brill.

Coulter, T. J. (2014). Transcultural aesthetics in the plays of Gao Xingjian. Basingstoke: Palgrave Macmillan.

Cowan, L. (2003). Introduction: The tragic abyss. In G. Arbery (Ed.), The tragic abyss (pp. 1-22). Dallas: The Dallas Institute Publications.

Domenach, J. M. (1967). Le retour du tragique. Essai. (The return of the tragic. Essay). Paris: Editions du Seuil.

Dutrait, N. (1996). L'écriture romanesque et théâtrale de Gao Xingjian (Gao Xingjian's fiction and dramaturgy). Paris: Seuil.

Fong, G. (1999). Introduction to the other shore. In G. Fong (Ed.), The other shore: Plays by Gao Xingjian (pp. IX-XLII). Hong Kong: The Chinese University Press.

Gao, X. (1995). Taowang (Escape). In Y. Hu (Ed.), Gao Xingjian xiju liu zhong (Vol. 4). Xindian shi: Dijiao chubanshe, minguo 84.

Gao, X. (1996). Juzuofa yu zhongxing yanyuan (Performance and the neutral actor). In X. Gao (Ed.), Meiyou Zhuyi (pp. 253-266). Xianggang: Tiandi tushu yuxian gongsi.

Gao, X. (1999a). Between life and death. In G. Fong (Ed.), The other shore: Plays by Gao Xingjian (pp. 45-80). Hong Kong: The Chinese University Press.

Gao, X. (1999b). Dialogue and rebuttal. In G. Fong (Ed.), The other shore: Plays by Gao Xingjian (pp. 81-136). Hong Kong: The Chinese University Press.

Gao, X. (1999c). Nocturnal wanderer. In G. Fong (Ed.), The other shore: Plays by Gao Xingjian (pp. 137-190). Hong Kong: The Chinese University Press.

Gao, X. (1999d). The other shore. In G. Fong (Ed.), The other shore: Plays by Gao Xingjian (pp. 1-44). Hong Kong: The Chinese University Press.

Gao, X. (2000). The case for literature. Gao Xingjian's Nobel prize lecture, translated by Mabel Lee. http://www.nobelprize.org/nobel_prizes/literature/laureates/2000/gao-lecture-e.html. Accessed July 2015.

Gao, X. (2007a). About "Escape". In G. Fong (Ed.), Escape and the man who questions death (pp. 69-72). Sha Tin: Chinese University Press.

Gao, X. (2007b). The man who questions death. In G. Fong (Ed.), Escape and the man who questions death (pp. 75-108). Hong Kong: Chinese University Press.

Gao, X., \& Fang, Z. (2010). Lun xiju (On drama). Taibei: Liangjin chuban shiye gufen youxian gongsi. Habachi, R. (1985). Il momento dell'uomo (Man's moment). Milano: Editoriale Jaka Book Spa.

Hathor, R. (1962). Tragedy, myth and mystery. Bloomington: Indiana University Press.

Hornby, R. (1986). Drama, metadrama and perception. Lewisburg, PA: Bucknell University Press.

Łabędzka, I. (2008). Gao Xingjian's idea of theatre: From the word to the image. Boston: Brill.

Lavine, T. Z. (1984). From Socrates to Sartre: The philosophic quest. New York: Bantam.

Lee, M. (2001). Pronouns as protagonists: On Gao Xingjian's theories of narration. In K. Tam (Ed.), Soul of chaos: Critical perspectives on Gao Xingjian (pp. 235-256). Hong Kong: The Chinese University Press.

Lee, G., \& Dutrait, N. (2001). Conversations with Gao Xingjian: The first 'Chinese' winner of the Nobel prize for literature. The China quarterly, 167, 738-748. 
Lukács, G. (1981). The metaphysics of tragedy. In R. W. Corrigan (Ed.), Tragedy: Vision and form (pp. 76-93). New York: Harper \& Row.

Mazzilli, M. (2015). Gao Xingjian's post-exile plays: Transnationalism and post-dramatic theatre. London: Bloomsbury.

Quah, S. R. (2004). Gao Xingjian and transcultural Chinese theatre. Honolulu: University of Hawaii Press.

Ricoeur, P. (1992). Oneself as another (K. Blamey, Trans.). Chicago: University of Chicago Press.

Sacco, D. (2013). Mito e teatro. Il principio drammaturgico del montaggio (Myth and theatre. The dramaturgical principle of montage). Milano-Udine: Mimesis.

Sartre, J. P. (1992). Being and nothingness (H. E. Barnes, Trans.). Washington: Washington Square Press.

Schlesier, R. (1993). Maenads as tragic models. In T. H. Carpenter \& C. A. Faraone (Eds.), Masks of Dionysus (pp. 89-114). Ithaca; London: Cornell University Press.

Soja, E. (1996). Thirdspace: Journeys to Los Angeles and other real-and-imagined places. Oxford: Basil Blackwell.

Steiner, G. (1961). The death of tragedy. London: Faber \& Faber.

Storm, W. (1998). After Dionysus: A theory of the tragic. Ithaca: Cornell University Press.

Szondi, P. (2002). An essay on the tragic. Stanford, CA: Stanford University Press.

Tam, K. (2001). Drama of paradox: Waiting as a form and motif in The bus stop and Waiting for Godot. In K. Tam (Ed.), Soul of Chaos: Critical perspectives on Gao Xingjian (pp. 43-66). Hong Kong: Chinese University Press.

Veg, S. (2010). Gao Xingjian and the role of Chinese literature today. Special Feature of China Perspectives, 2, 34.

Vernant, J. (1986). Le dieu de la fiction tragique (The god of tragic fiction). In J. Vernant \& P. VidalNaquet (Eds.), Mythe et tragédie en Grèce ancienne/t.2 (pp. 17-24). Paris: La Découverte.

von Held, P. (2011). Alienation and theatricality: Diderot after Brecht. London: Legenda.

Zhao, H. (2000). Towards a modern zen theatre: Gao Xingjian and Chinese theatre experimentalism. London: School of Oriental and African Studies, University of London. 